\title{
POLLUTED IRRIGATION WATERS AS A RISK FACTOR TO PUBLIC HEALTH
}

\author{
Armen Saghatelyan ${ }^{\mathrm{a}}$, Lilit Sahakyan ${ }^{\mathrm{a}}$, Olga Belyaeva ${ }^{\mathrm{a}^{*}}$ \\ ${ }^{a}$ The Center for Ecological-Noosphere Studies NAS RA, 68 Abovian Str., 0025 Yerevan, Republic of Armenia \\ phone: (+374 10)572924, fax: (+374 10)572938, e-mail: ecocentr@sci.am, http://www.ecocentre.am, *olgabel80@gmail.com
}

\begin{abstract}
Complex investigations of agro-ecosystems adjacent to a huge mining set of plants located within the city of Kapan were performed with a goal to identify risk factors to the health of local populace. A basic factor of pollution of agro-ecosystems is heavy metal enriched ore waters from adits and industrial water streams freely emptying into the irrigation network. Farm crops growing under conditions of pollution accumulate a series of heavy metals and microelements.
\end{abstract}

Keywords: heavy metals, irrigation water pollution, soil pollution, crops pollution.

\section{Introduction}

The impact of irrigation waters on public health is manifested indirectly; it practically always is mediated by the impact upon the quality of the obtained farm crops. A long-term use of irrigation waters polluted with toxic metals and microelements results in accumulation of such elements in farmland soils and their migration in system "soil-plant" $[1,2]$.

The issue of environmental pollution with heavy metals is of special topicality in mining sites where farmlands are exposed to the impact of mining plants [13].

One of Armenia's huge mining centers is located in the city of Kapan. The city lies in the southwest of the country, on River Voghchi valley. The region's territory was characterized by V.V. Kovalski [5] as a natural copperenriched biogeochemical province.

Kapan's mining set comprises the objects of ore extraction and treatment as well as industrial waste centralized in a giant tailing repository of Artsvanik. The development of Kapan deposit started in 1846 and has been progressing since then. A long-term operation of the noted mining complex have resulted in pollution of practically all environmental compartments of the city and neighboring sites $[3,10,11,14]$. A characteristic feature of pollution is superposition of man-made haloes of heavy metal distribution on natural geochemical anomalies [12].

Wholly, the noted region is characterized by intense agricultural development of river valleys. The vastest farmlands are the city neighboring lands of the Syunik community (Fig. 1). The farm crops growing there are a basic food products for the population of the cities of Kapan and Kajaran as well as of adjacent villages. The farmlands of village of Syunik are irrigated by the waters of River Voghchi tributaries.

With a goal of sanitary and hygienic assessment of farm crops grown within a mining plants impact zone, studied were the contents of heavy metals in irrigation waters and soils as well as in basic vegetable, herb and fruit species.

\section{Materials and methods}

Irrigation water samples were collected into plastic containers with a $0,5 \mathrm{~L}$ volume and then conserved with concentrated nitric acid 3. Soil and farm crops samples were collected into polyethylene bags [6] and then air - dried and treated consistent with ISO methods [1].

The analyses were performed in the ISO17025 - accredited Central Analytical Laboratory of the Center for Ecological-Noosphere Studies NAS RA on a PerkinElmer AAS AAnalist 800 following standard ISO methods [1]. Determined were the contents of $\mathrm{Hg}, \mathrm{Cd}, \mathrm{As}, \mathrm{Pb}, \mathrm{Cu}, \mathrm{Mo}, \mathrm{Zn}, \mathrm{Ni}$, and $\mathrm{Cr}$.

No MAC values for some elements have been developed in Armenia, so those for a series of studied metals were taken from diverse literature sources (Tab.1).

\footnotetext{
『 This article is an extended abstract of a communication presented at the Conference Ecological Chemistry 2012
} 


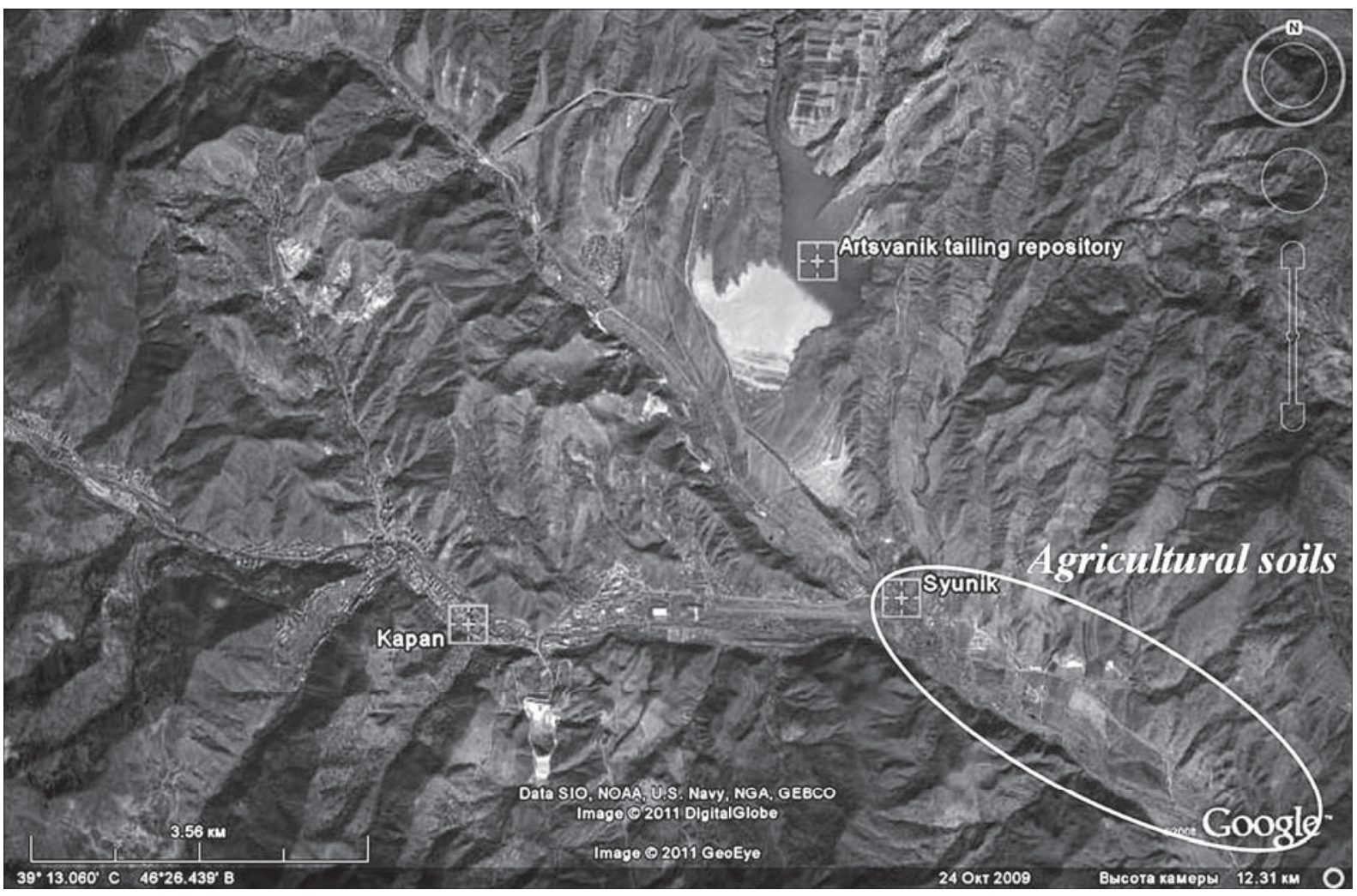

Fig. 1. The territory of the city of Kapan and adjacent farmlands

Table 1

MAC values of elements for different substrates.

\begin{tabular}{|c|c|c|c|c|c|c|c|}
\hline \multirow{3}{*}{ Elements } & \multicolumn{7}{|c|}{ Environment } \\
\hline & \multirow{2}{*}{$\begin{array}{c}\text { Waters, } \\
\text { by }[4] \\
\mu \mathrm{g} / \mathrm{L}\end{array}$} & \multicolumn{2}{|c|}{ Soil, mg/kg } & \multicolumn{4}{|c|}{ Farm crops, mg/kg } \\
\hline & & by [6] & by [9] & $\begin{array}{c}\text { Vegetables } \\
\text { by [7] }\end{array}$ & $\begin{array}{l}\text { Fruits } \\
\text { by [7] }\end{array}$ & $\begin{array}{c}\text { Vegetables } \\
\text { by [4] }\end{array}$ & $\begin{array}{l}\text { Fruits } \\
\text { by [4] }\end{array}$ \\
\hline $\mathrm{Hg}$ & 0,5 & 2,1 & - & 0,02 & 0,02 & \multirow{4}{*}{-} & \multirow{4}{*}{-} \\
\hline $\mathrm{Cd}$ & 1 & \multirow{8}{*}{-} & 2 & 0,03 & 0,03 & & \\
\hline As & 50 & & 2 & 0,2 & 0,2 & & \\
\hline $\mathrm{Pb}$ & 30 & & 65 & 0,5 & 0,4 & & \\
\hline $\mathrm{Cu}$ & 1000 & & 132 & \multirow{5}{*}{-} & \multirow{5}{*}{-} & 5 & 5 \\
\hline Mo & 250 & & 132 & & & 2 & 2 \\
\hline $\mathrm{Zn}$ & 5000 & & 220 & & & 10 & 10 \\
\hline $\mathrm{Ni}$ & 100 & & 80 & & & 0,5 & 0,5 \\
\hline $\mathrm{Cr}$ & 50 & & 90 & & & 0,1 & 0,1 \\
\hline
\end{tabular}

Note: “_" - a standard either has not been developed or wasn't used in this work.

\section{Results and discussion}

The farmlands of a village of Syunik are irrigated by waters of the tributaries of the major water artery to the region - River Voghchi: the Syunik, Norashenik and Artsvanik rivulets. The noted natural water streams are mixed with untreated ore waters from adits as well as with waters from industrial aqueducts of the Kapan plant and the Artsvanik tailing repository.

Investigations of natural water streams indicated that for the studied period heavy metal contents in river water did not overstep MAC values established in Armenia for natural waters [4] (Fig. 2).

In contrast to natural water streams, the adit and industrial aqueduct waters displayed concentrations of a scope of heavy metals namely $\mathrm{Cu}, \mathrm{Zn}, \mathrm{Cd}$, As, $\mathrm{Hg}$ which were notably excessive vs. MAC values (Fig. 3). 


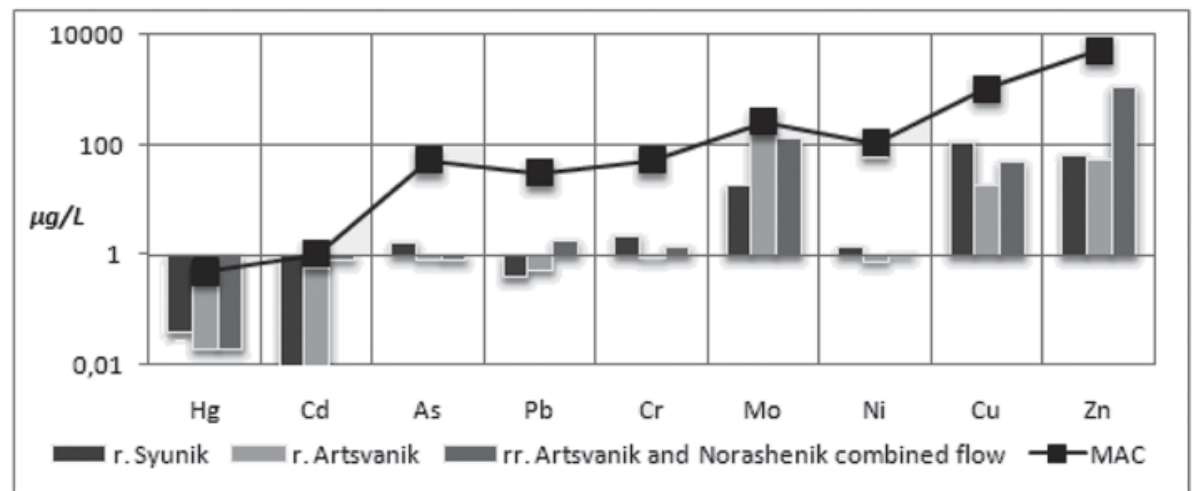

Fig. 2. Heavy metal concentrations in the waters of River Voghchi tributaries and MAC values for water [4]

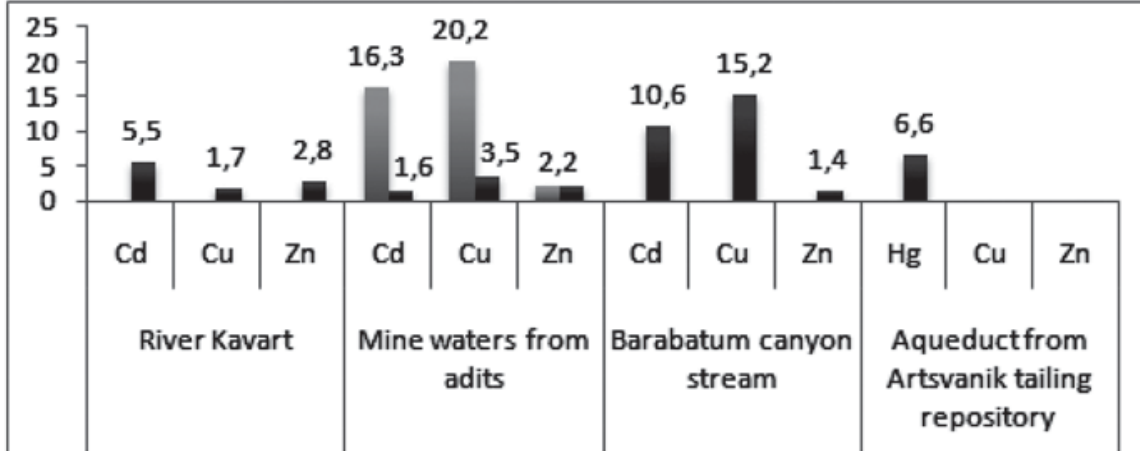

Fig. 3. Excessive concentrations of heavy metals in the waters of industrial and mixed water streams vs. MAC valus for water [4]

Factual contents of heavy metals in soils as well as their geochemical background and MAC are highlighted in Fig. 4. A geochemical series of soils ranked by excesses of factual concentrations of metals against the background is as follows: $\mathrm{Cu}_{(4,8)}-\mathrm{Mo}_{(2,3)}-\mathrm{Ni}_{(1,4)}-\mathrm{Cr}_{(1,2)}$, summary intensity of the series being equal to 9,7. Dominating pollutants of farmlands are $\mathrm{Cu}$, Mo and $\mathrm{Ni}$, their share in summary intensity making 66\%.

As seen from the given data, the contents of most studied metals in soils exceed the geochemical background, this being a consequence of the use of irrigation waters polluted with heavy metals.

MAC - exceeding values were established for $\mathrm{Cu}-$ by 6 , Mo -4 and $\mathrm{Ni}-2,4$ times. It is noteworthy, that concentrations of elements of the $1^{\text {st }}(\mathrm{Pb}, \mathrm{As}, \mathrm{Zn})$ and $2^{\text {nd }}(\mathrm{Cr})$ grades of danger make $60-83 \%$ of MAC value [6,9]. The research indicated a presence of $\mathrm{Cd}$ and $\mathrm{Hg}$ in soils in concentration lower than MAC.

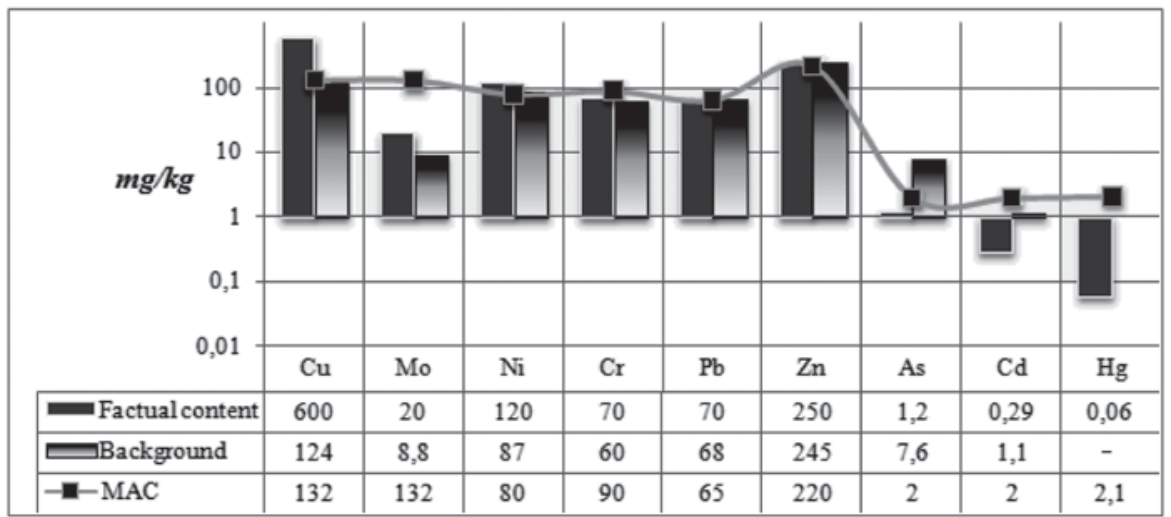

Fig. 4. Concentrations of heavy metals in farmland soils vs. their geochemical background and MAC values

The performed research covered a wide scope of farm crops obtained in village of Syunik. Practically in all the studied vegetable, fruit and herb species concentrations of $\mathrm{Cr}$, $\mathrm{Ni}$ and $\mathrm{Pb}$ considerably exceeded $\mathrm{MAC}$ values [7]. $\mathrm{Cu}, \mathrm{Zn}$ and Mo concentrations were insignificant, but in some cases they, too, exceeded MAC values [4] (Fig. 5). Particularly hazardous are excessive contents of $\mathrm{Hg}$ vs. MAC which were indicated in farm crops grown on lands irrigated by waters from the Artsvanik tailing repository. 
In the majority of farm crop samples As and Cd concentrations were either lower than MDL (Minimum Detection Limit) or did not overstep MAC values [7].
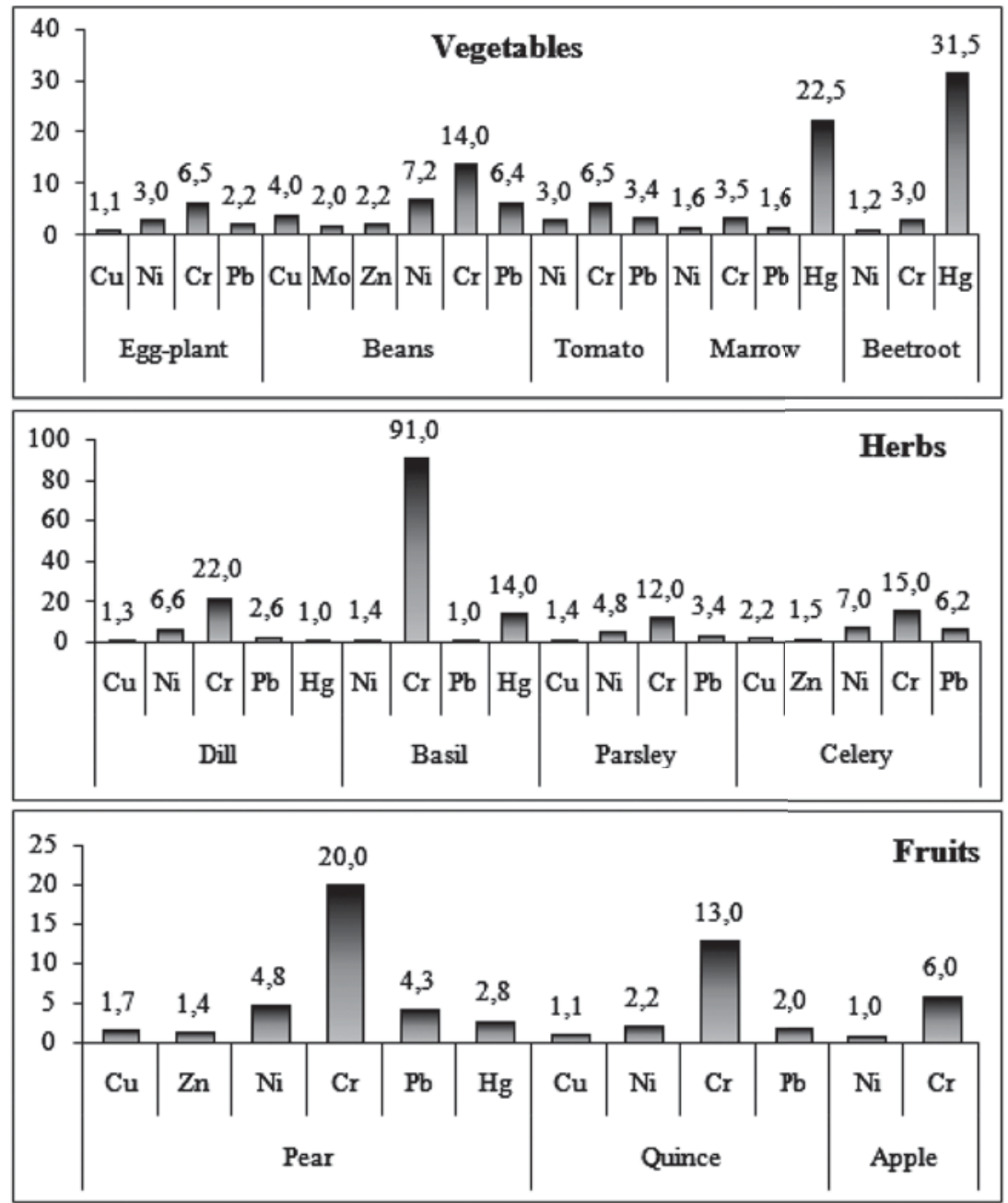

Fig. 5. MAC - exceeding concentrations of heavy metals in some farm crops $[4,7]$

To characterize the intensity of heavy metal transfer from soils to plants, a biological accumulation factor (BAF) was calculated which means relation between a chemical element concentration in plant tissues and its concentration in soil: $B A F=C_{\text {crop }} / C_{\text {soil }}$ (Fig. 6).

As seen from the data, most intensively farm crops accumulate $\mathrm{Hg}$. The highest BAF values were established for beet roots, vegetable marrows and green mass of basil. Hg concentrations in the tissues of the noted plants were 2-10,5 times excessive vs. those in soils. It should be noted that a mercury source is polluted irrigation water. High values of BAF were established for Mo and $\mathrm{Cr}$, too, in bean peas, corn ears, and green mass of basil.

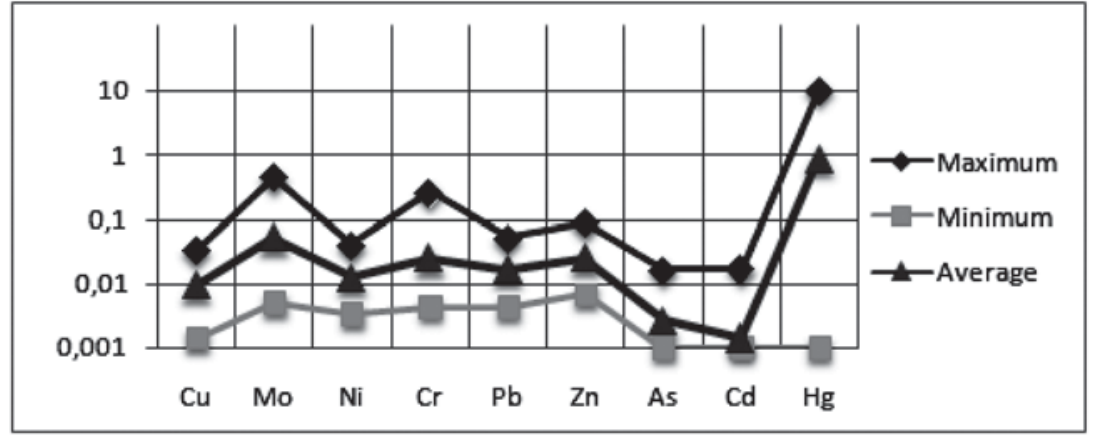

Fig. 6. A biological accumulation factor 


\section{Conclusion}

The complex investigations indicated that a basic factor of pollution of huge agro-ecosystems adjacent to the city of Kapan are ore and industry-induced waters either emptying into the irrigation network or directly used for irrigation purposes. Long-term irrigation of farmlands with polluted irrigation waters results in accumulation of a set of elements on arable soil layer. The farm crops obtained in the region is hazardous to be used as it contains standard-exceeding concentrations of a set of heavy metals including such toxic elements as $\mathrm{Pb}$ and $\mathrm{Hg}$. Intense accumulation of heavy metals in plants occurs as a result of using polluted irrigation waters, this making them a risk factor to public health.

\section{References}

[1]. Analytical methods for atomic absorption spectrometry. PerkinElmer, BS EN ISO, 9001.

[2]. Appenroth Klaus-J. Chapter. 2. Definition of heavy metals and their role in biological systems. Soil Heavy Metals Series: Soil Biology, Vol. 19 Sherameti, Irena; Varma, Ajit (Eds.), 2010, pp. 19-29.

[3]. Artiola J.F. Monitoring Surface Waters. Environmental Monitoring and Characterization. ELSEVIER Academic Press, 2004, pp. 141-161.

[4]. Dueck T.A., et al., 1984: Heavy metal emission and genetic constitution of plant population in the vicinity of two metal emission sources. - Angew. Bot., v. 58, №1.

[5]. Kovalsky V.V., 1974. Geochemical Ecology. Moscow, Nauka, 300 pp. (in Russian).

[6]. Resolution № 01-N as of 25 January 2010. About approval of sanitary guidelines and norms №2.1.7.003-10 "Soils quality hygienic requirements" RA Ministry of Health. Electronic source, www.arlis.am, open access (in Armenian).

[7]. Resolution №181 as of March 28, 2008 «About approval of sanitary guidelines and norms N 2-III-4.9-01-2003 to the requirements to raw foodstuff and food safety and food prices. Electronic source, www.arlis.am, open access (in Armenian).

[8]. Resolution №876 as of December 25, 2002. “About approval of sanitary guidelines and norms № 2-III-A2-1 "Potable water. Hygienic requirements to waters quality" RA Ministry of Health Electronic source, www.arlis. am, open access (in Armenian).

[9]. Resolution of the RA Government N 92 $2^{\text {ammended }}$ as of January 25, 2005 "About approval of the procedure of assessment of the economic activities - induced impact upon soil resources". Electronic source, www.arlis.am, open access (in Armenian).

[10]. Saghatelyan A., Sahakyan L., Belyaeva O. Environmental impact of mining on system water-soil-crop. Proceedings of the 1st International Applied Geological Congress. 26-28 April 2010 Masshad, Iran, 2010, pp. 22092213.

[11]. Saghatelyan A., Sahakyan L., Belyaeva O., Mikayelyan M. Heavy metals accumulation in system soil - farm crops under the impact of mining industry. Articles of the 1st Symposium on Medical Geology, 14-16 June 2010, Tehran, Iran, pp. 38-46.

[12]. Saghatelyan A.K. The peculiarities of heavy metals distribution on Armenia's territory. Yerevan, The Center for Ecological-Noosphere Studies of NAS RA, 2004, 157 p.

[13]. Saghatelyan A.K., Gevorgyan V.Sh., Arevshatyan S.H., Sahakyan L.V. Ecological and geochemical assessment of environmental state of the city of Kajaran. Yerevan, The Center for Ecological-Noosphere Studies of NAS RA, 2008, 200 p.

[14]. Saghatelyan A.K., Sahakyan L.V., Mikayelyan M.G., O.A. Belyaeva. Ecological and geochemical analysis of risks of the impact of mining production upon sustainable development of Armenia. Izvestiya RAN. Seriya geograficheskaya 2010, N5, pp. 94-100.

[15]. Wilson L.G., Artiola J.F. Soil and vadose zone sampling. Environmental monitoring and characterization. ELSEVIER Academic Press, 2004, pp. 101-119. 